TRAMES, 2009, 13(63/58), 4, 357-373

\title{
HISTORICAL GEOGRAPHY OF ESTONIAN CATTLE BREEDS
}

\author{
Taavi Pae ${ }^{1}$, Erki Tammiksaar ${ }^{1,2}$, and Helen Sooväli-Sepping ${ }^{3}$ \\ ${ }^{1}$ University of Tartu, ${ }^{2}$ Estonian University of Life Sciences, and ${ }^{3}$ Tallinn University
}

\begin{abstract}
The cattle breeds that have been exploited in European countries have evolved through centuries. The characteristics of specific breeds have been determined by their habitation, i.e. by the surrounding natural and geographical environment. This determined the nutrition, the anatomic features, the milk yield, the fat content in milk, the muscle mass etc. The present article will show that in addition to the natural conditions also administrative division may lead to different cattle breeds being bred on a territory with relatively similar vegetation as well as climatic, geographic and demographic conditions. One of such territories is the area inhabited by Estonians that became a part of the Russian Empire in 1721 as the Provinces of Estonia and Livonia (the Northern part of the latter). The province was unified after the February revolution in 1917, and in 1918 the Republic of Estonia was born. The insight into the history of cattle breeding in Estonia, illustrated by distribution maps of main cattle breeds, will show that even today these administrative boundaries that ceased to exist long ago, still have an impact on cattle breeding in Estonia.
\end{abstract}

DOI: $10.3176 /$ tr.2009.4.03

Keywords: Estonia, Livonia, cattle breeding history

\section{Introduction}

The geographical distribution of cattle breeds is a topic not given much attention by the international research community. While there are some general studies and encyclopaedias that provide general data about the distribution of breeds, no real detailed research exists (see e.g. Frahm 1982). However, during the last decade, much work has been done in the evaluation of the genetic material of cattle herds and the resultant variations within them (Kantanen et al. 2000, Torok 1995, Lenstra 2006). Studying the genetic material of cattle undoubtedly adds a new perspective to the history of European agriculture and sheds light on the geographical distribution of cattle breeds. This article, utilising the methods of historical geography, studies and analyses data from different cattle pedigree 
books, information about the distribution of cattle, and facts about the historical conditions of cattle breeding in Estonia.

The territory of the present-day Republic of Estonia has been subjected to occupations of several foreign powers throughout its history. Estonians have been ruled by the Danes, the Poles and the Russians; its territory has been divided, sometimes even simultaneously, between the aforementioned nations into several parts (see Pistohlkors 2002, Palmer 2005). The longest rulers though were the Germans, who became local aristocracy over the centuries, even during the reign of other nations over Estonia. This complicated political history has left its mark on the development of administrative areas within the country. Estonia was relatively homogeneous in its population and landscape until its conversion to Christianity at the beginning of the 13th century, at which point it was divided into North-Estonia, which belonged to the Danes, and South-Estonia, that belonged to the Livonian Order (branch of the Teutonic Order) and the Bishop of Riga. This border between North and South was determined by the natural geographical characteristics of Estonian territory - specifically bogs. This border area was, and still is, traversed by an East-West directional zone of bogs (Külvik et al. 2000). This eventually became a permanent administrative border as knighthoods developed in the region. The German-speaking aristocracy formed one knighthood in North-Estonia (Estonia Province, capital in Tallinn), while South-Estonia together with North-Latvia (Livonia Province, capital in Riga) had their own knighthood. Additionally, Saaremaa had its own knighthood separate from the others (see Figure 1). The governors of these separate provinces had their own privileges, laws, currency and units of measure. Although Estonia became a part of Tsarist a Russia after the Great Northern War (1700-21), its tight connections with Western Europe, the original founders of the northern and southern provinces, were sustained. While formally belonging to the Russian Empire, the Baltic Provinces enjoyed the Baltic Landesstaat ${ }^{1}$ and the large population of Baltic Germans that lived in the region kept close contacts with their native land. These close connections facilitated the rapid transfer of cultural and economic developments that were taking place in Western European countries at the time to the eastern coast of the Baltic Sea. Compared to other regions of the Russian Empire, the Baltic Provinces were more advanced in terms of economic and cultural development, including cattle breeding. ${ }^{2}$ This historical border and connections with Western Europe would eventually play an important part in the development of cattle breeding in Estonia.

1 The Baltic Landesstaat was an administrative policy in the Estonian and Livonian provinces, which belonged to Tsarist Russia after the Great Northern War. The Baltic Landesstaat was based on specific laws governing this region, which differed from the rest of Russia.

2 For example, the first higher school of agriculture in Tsarist Russia - The Agricultural Institute of Vana-Kuuste - was founded in Tartumaa, Livonia, in 1834 by professor Johann Friedrich Leberecht Scmaltz (1781-1874) in order to train the students of Tartu University specialized in agriculture how to conduct field work. 


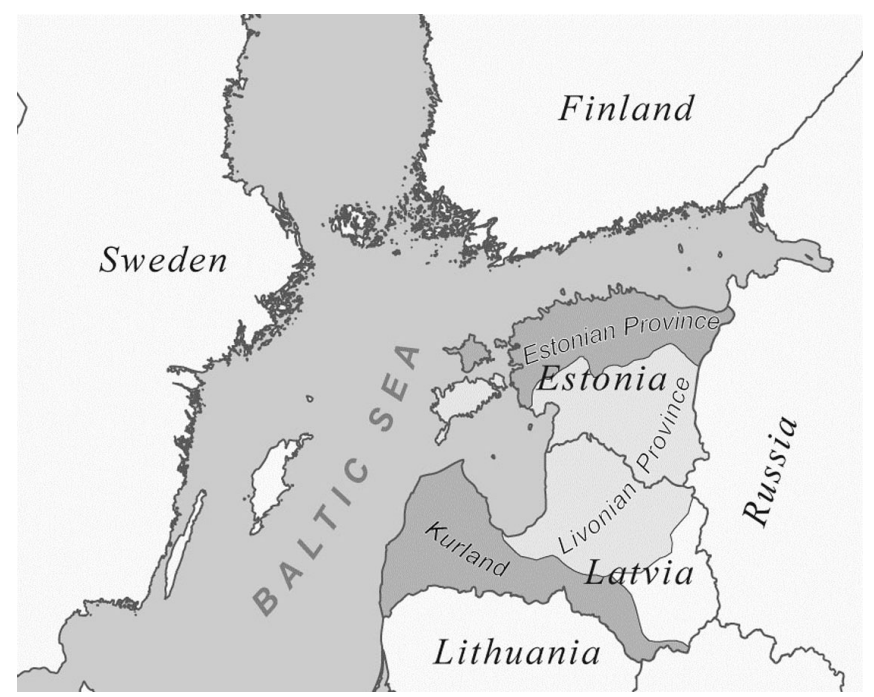

Figure 1. Geographical position of Estonian Province, Livonian Province and Kurland (early 18th century to early 20 th century).

\section{Historical development of Estonian cattle breeds, historiography}

While the history of cattle breeding in Estonia has been examined by researchers (e.g., see Keyserling 1894, Stegmann 1923, Kivimäe 1994, Kutti et al. 1965, Mölder 1949, Pung 1985), the geographical distribution of cattle breeds has been of little interest. Estonia has been an agricultural country throughout its entire history. At the beginning of the Common Era, agriculture became a significant source of subsistence. By the end of the 19th century, it had become the most important source of industry and remained the leading industry within the Republic of Estonia during the 1930s. The first written records of cattle breeding in Estonian territory originate from the Livonian Chronicle written by Henry of Livonia at the beginning of the 13th century (The chronicle of Henry of Livonia 1961). The Chronicle indicates that Estonians already had many cattle at that time and that from a campaign to Soontagana in 1210/11, four thousand cattle were taken as plunder. ${ }^{3}$ The sizes of herds were also praised by other chroniclers, like the Russow Chronicle from the 16th century (The Chronicle of Balthasar Russow 1988). The first known data that confirms the search for a cattle breed suitable for the territory of Estonia dates all the way back to the 17th century. There are records indicating that Dutch cattle were bred in Purtse manor, Viru County, Estonia in 1624 (Karelson 1981). Furthermore, in the first thorough description of the territory of Estonia - "Topographische Nachrichten von Lief- und Ehstland" by August Wilhelm Hupel - the author mentions that cattle were bred quite

3 Though the data from Henry of Livonia was probably exaggerated, it is surprising that there are much less cattle in that area (Koonga Parish) nowadays (1445 cattle) (ARIB 2005). 
extensively in Estonia and that the animals were smaller than those in other Russian provinces, Germany, and Denmark (Hupel 1777). Unfortunately, the text did not mention the breeds of cattle. Individual reports on the breeding of different cattle breeds in the manors of Estonia originate from the 18th century and from the beginning of the 19th century (see e.g. Stegmann 1924). According to Meinhard Karelson (1981), an expert on the history of Estonian cattle breeding, almost all popular Western European cattle breeds existed in Estonia in the 1850s. However, unlike in other European countries, no systematic breeding work with cattle was practised. Many cattle breeds were not suitable for the climatic conditions of Estonia and Livonia, as they originated from areas with different climatic and nutritional conditions. Consequently, the oldest agricultural society in the Baltic Provinces - the Livonian Benefit and Economic Society (established in 1792) failed in improving the Estonian native cattle with Arshire oxen because the climatic conditions of Estonia were unsuitable for cattle from the Scottish highlands (Lepajõe and Oll 1998).

Cattle breeding eventually became more systematic in the Baltic Provinces under the Russian Empire in the second half of the 19th century, mainly because of increasing competition in the European market of agricultural products. In order to ensure a market for their agricultural production, the Baltic German landlords had no other choice than to increase production and find ways to improve the native cattle. Alexander Theodor von Middendorff (1815-1894), a Baltic German scientist, was the most notable cattle breeder during this period in Livonia. His Baltic German background was somewhat interesting as his father was a nobleman, while his mother was an Estonian peasant. Middendorff was born in St. Petersburg and attended school there at an early age, but later moved to Tartu and attended Tartu University to study natural sciences under the Faculty of Medicine. Since his childhood, Middendorff had been an enthusiastic hunter and always very interested in rural life, as he was very active in the management of his father's estate in Livonia. During an expedition to northern and eastern Siberia, which lasted from 1842 to 1845 , he made significant observations on agricultural practices and taxation systems employed in the regions. The expedition expanded his scientific reputation, but had negative effects on his health and physical condition. Middendorff eventually bought his own estate in Livonia in 1850 and continued to pursue his interest in the complex issues of Livonian agricultural policy, the regulations of which were mainly in favour of the interests of Baltic German landlords. A reform plan launched in 1840 suggested a shift from corvée to personal freedom and the selling of land to peasants; however, it was not binding for the landlords to follow this plan. Middendorff, who was a member of the St. Petersburg Academy of Sciences and an elected member of the Academy of Zoology, travelled extensively in Russia and Western Europe, and as a result, obtained extensive knowledge on the overall practices in agricultural policy. $\mathrm{He}$ observed that various European countries gradually introduced common agricultural regulations similar to each other, which leaned towards large farms with intensive production. Russia, including Livonia, still followed old agricultural 
practices. Middendorff realised that Livonia might lose its agricultural market and suggested that new scientific methods should be applied, both by landlords and peasants, in order to compete with other European and Ukrainian producers, who lived in more favourable climates. In 1861, Middendorff returned to Livonia from St. Petersburg due to health problems and became head of the Livonian Benefit and Economic Society (1862-1882). Its membership was not accessible to everyone, it had little authority to introduce new practices to the public. Middendorff made an effort to open the Society to all interested parties with the intention of providing everyone with information about new methods in agricultural production. This would enable Livonia, as a whole, to become agriculturally more fruitful. The key issue to improving Livonia's agricultural development, Middendorff believed, was the improvement of dairy production. He considered the raising of dairy cattle to be more favourable than beef cattle (Tammiksaar 2006, Sukhova and Tammiksaar 2005).

Even though many of the leading Livonian manor farms were qualitatively, as well as quantitatively, productive, Middendorff claimed their outputs were not enough to guarantee the competitiveness of Livonia's agricultural products. $\mathrm{He}$ once stated:

The isolated endeavours of our landlords to achieve eminent position in the world market with their production fail, because they are never capable of it on their own. To gain success, the whole country has to have the same ambitions and goals, because the quality [of the merchandise] in massive quantities is the only thing that counts in world markets. If we do not wish to be left aside, our most urgent task is to produce and trade more than up to the present [underlining by Middendorff]. ${ }^{4}$

Although he claimed that dairy farming was the basis for a boom in agriculture, Middendorff considered the intensification of agricultural production in all strata to be important for the development of Livonia. However, development would not flourish without systematic breeding work with native cattle, as cattle breeding was the way to stay competitive in the dairy market. To improve the pedigree of native Estonian cattle, a suitable breed accustomed to similar climatic conditions had to be found. In the late summer of 1862, Middendorff found several candidates from among the Red Angler cattle breed in Schleswig-Holstein and Denmark and chose 31 Anglers from among 880 in the area of Tondern and the Lügum Monastery in Denmark to begin breeding. ${ }^{5}$ With these animals, his aim was to breed cattle that could produce a high milk yield and could adapt to living in the natural conditions of Livonia. By 1863, he had achieved very positive results with the Angler breed (Baltische ... 1863, Verhandlungen ... 1864) and the new cattle became quite popular among the landlords of Livonia. The import of a new cattle breed and the uncontrolled improvements of the local breed led Middendorff to begin identifying the characteristics of the native cattle breed in

\footnotetext{
${ }^{4}$ Estonian Historical Archive: 1185-1-372, 1. 5 p.

${ }^{5}$ Estonian Historical Archive: 1185-1-372, 1. 2-5.
} 
order to control the improvements. To do this, accurate data on the origin, age, calving, milk yield, milk quality, and provender of the cattle had to be gathered (Baltische ... 1871). Landlords and peasants followed Middendorff's data collection instructions and by 1879, Livonia had achieved notable advancements in improving the breed (Baltische ... 1879). The next step in raising the breed value of the new cattle was recording the individual breed characteristics of the best specimens into pedigree books. In 1884, Middendorff proposed to start recording the breed characteristics and in 1885 the Baltic Cattle Breeders Association was founded, which kept strict records of different cattle breeds in pedigree books (Baltisches ..., 1886). The Breeders Association decided that the weight of the new developing breed needed to be increased and so the import of larger Danish Red Funen cattle to Livonia began in 1892 (Mägi 1924). The mixing of the two imported Danish breeds and the native cattle served as a basis for the creation of a new Livonian Red cattle breed and, subsequently, was responsible for a dairy farming boom in Livonia. By the end of the 19th century, the Province of Livonia had become the most advanced agricultural area in the entire Russian Empire.

North-Estonia (the Province of Estonia) began developing its own breed of cattle in the middle of the 1880s, considerably later than the cross-breeding efforts in South-Estonia (the Province of Livonia). Whereas Angler and Funen breeds were brought to Livonia, the Holstein and the East-Friesland cattle breeds, which also produced high milk yields, were imported to Estonia (Bodisco 1894). The instigator of agricultural progress in Estonia was the Estonian Agricultural Association, which was founded in 1844. The association's first real leader was Alexander von Keyserling (1815-1891), a palaeontologist from Kurland, who took control of the organization in the 1850s. He originally studied at Berlin University and was later employed in Russia as a civil servant. In the early 1840s, he organized three expeditions into the European part of the Russian Empire (two of them with Sir Roderick Murchison). Keyserling's academic career did not last long as his wife frequently suffered from poor health and his family decided to move to Estonia where his father-in-law, Feodor Cancrin - the Minister of Financial Affairs of Russia, had given them several manor estates as a wedding present. Keyserling was very active with the agricultural success of his estates and successfully intertwined them with the activities of the Estonian Agricultural Association.

Count Leo von Keyserling (1849-1895), the son of Alexander von Keyserling, had even more influence in the promotion of agricultural policy within the Estonian Agricultural Association. Having a wide-ranging knowledge of agricultural practices, he continued his father's responsibilities both in management of his estates and leading the Association in 1893. Although both father and son had much respect for Middendorff, they believed the introduction of the Holstein cattle to the region would bring about better economic prosperity as the Holstein produced a higher milk yield than Middendorff's Red cattle. Count Keyserling dedicated all his energy to improving the breed of Estonian dairy cattle (Kivimäe 1994). As a result of cross-breeding the Holstein and the East-Friesland cattle with 
the native cattle, the Estonian Black-and-White (also known as Estonian Holstein) cattle breed was created. Just like the Red cattle breed of Livonia, the characteristics of the Estonian Black-and-White cattle were recorded in pedigree books.

By the end of the 19th century, most Estonian (the Estonian Province and Northern part of Livonian Province) households were still raising native cattle. However, due to rapid economic development within the Russian Empire, by the beginning of the 20th century, the new distinct cattle breeds had replaced the native cows and had become prevalent in both provinces (Lepajõe and Oll 1998). After Estonia gained its independence in 1918, cattle breeding activities continued to flourish and dairy products became the country's most important items of export (primarily to Denmark and England). The Breeders Associations of Estonian Angler and the Breeders Association of Estonian Black-and-White Dairy Cattle were both established in 1919, and a Breeders Association of Estonian Native Cattle was established in 1920. Whereas breeding activities during the previous years were mainly the responsibility of individual landlords, these new associations worked with each other to improve cattle breeding within the entire country. A network of test stations was developed during the 1920s and 1930s, which organized breed shows and conducted artificial inseminations on cattle in order to help the breeds proliferate (Saveli 2006). These efforts ensured the stable development of all three breeds of dairy cattle in Estonia.

During the Soviet period, animal breeding was reorganized in Estonia with the creation of the Research Institute of Animal Breeding and Veterinary Medicine at the Academy of Sciences of the Estonian Soviet Socialist Republic in 1947. The work of the institute was controlled by the government, mainly based on the guidelines set forth in the "Means for developing agriculture in the post-war period" from the Central Committees of Estonian Communist Party XVI plenary session (5th of April 1947). According to this decree, the improvement in the quality of the breed of farm animals was of the utmost importance and should be an actively targeted goal. Organizations coordinating the breeding of cattle were founded and work with the Estonian Red cattle began in 1947 and with the Estonian Holstein cattle in 1948 (Põlluäär 2004, Bulitko et al. 2004). These organizations became centres for cattle breeding; however, the main difference from the pre-war period was that now breeding was done mainly in collective farms. The organization promoting native cattle was not re-established in the Soviet period and thus might be the reason why the number of native cattle decreased drastically after the Second World War. In 1956, agricultural institutes were placed under the supervision of the Ministry of Agriculture in each of the Soviet republics, including Estonia. That same year, the Estonian Livestock Breeding and Veterinary Institute (ELVI) was established, which became the main centre for animal breeding until Estonia regained its independence in 1991, at which point the ELVI was joined with the Estonian Agricultural University (now Estonian University of Life Sciences). After the second independence in 1991, cattle breeding continued to take place in breeding organizations, except this time, the Estonian Native Cattle Association was re-established to coordinate the breed- 
ing of native cattle. Today, Estonian native cattle are on the endangered breeds list of the FAO (Food and Agriculture Organization) (Kalamees 2004, Kalamees 2007). In addition to the mentioned breeding organizations, an Estonian Beef Breeders Association was established in 2003 and all of these organizations were united under the umbrella of the Animal Breeders Association of Estonia in 1993.

\section{Data and methodology}

This article analyzes the geographical and numerical distributions of Estonian cattle breeds and the conditions that have caused the particular distributions from the 1860s until today. Moreover, we wish to check the claims of previous researchers that the Estonian Red cattle is bred mainly in South-Estonia and the Estonian Holstein cattle mainly in North-Estonia (e.g., see Kukk 2002, Jaanhold 1927, Eesti rahvaleksikon (1937-40). Early statistical data used in this research paper has been obtained from an article on the development of dairy farming before 1918 by Kivimäe (1994) and from books on agricultural statistics until 1940. The sources of data from the Soviet period are productivity control reports of cattle in 1976 (Idarand 1978). The most recent data come from the database of Estonian cattle breeds by the Estonian Agricultural Registers and Information Board (ARIB) from November 2005. The data from 1976 has been processed to be comparable with the contemporary administrative system and, because of this, some imprecision may occur on the distribution map of the cattle. However, this does not affect the overall picture of distribution. The distribution map of the cattle from 1976 does not cover the cattle bred in households; it covers only the cattle bred in collective farms, on which only the official data is available. Information about the borders between the Soviet rural municipalities originates from a CD of Estonian Geography (Roosaare et al. 2000).

\section{The number and location of Estonian cattle breeds - analysis and results}

As it appears from Table 1, the ratio between the Estonian Holstein and the Estonian Red - the two most widespread breeds - was relatively equal throughout the territory of Estonia at the end of the 19th century. However, differences between cattle breeds due to location are notable. It has to be mentioned that most of the cattle in Estonia were not necessarily pedigree at the beginning of the 20th century. Even in the control year 1938/39, pedigree cattle formed only 11 percent of the total number of cattle. However, this percentage reflects only the number of pure pedigree cattle; the number of cattle having pedigree characteristics was certainly much larger. As the 20th century progressed, the ratio balance shifted in favour of the Estonian Red cattle breed. For example, in 1939, 73 percent of all cattle controlled were Estonian Red (Eesti karjakontoll ... 1940); the reason for this being that South-Estonia was the most prosperous part of Estonia in those years 
Table 1. Distribution of cattle breeds in Estonian manor herds in 1898 (Kivimäe 1994)

\begin{tabular}{lccc}
\hline County & Dutch-Friesian (Holstein) & Angler-Funen (Red) \\
\hline Harju County & 4912 & 1085 \\
Viru County & 5617 & 2495 \\
Järva County & 2167 & 590 \\
Lääne County & 3869 & 1970 \\
Total North-Estonia & $\mathbf{1 6 5 6 5}$ & $\mathbf{6 1 4 0}$ \\
Tartu County & 867 & 7858 \\
Võru County & 1141 & 5007 \\
Viljandi County & 1144 & 4800 \\
Pärnu County & 1507 & 2178 \\
Total South-Estonia & $\mathbf{4 6 5 9}$ & $\mathbf{1 9 8 4 3}$ \\
Saaremaa County & 1209 & 781 \\
Total Estonia & $\mathbf{2 2 4 3 3}$ & $\mathbf{2 6 7 6 4}$ \\
\hline
\end{tabular}

(Kant 1935) and the cattle bred there were set as a good model for what cattle should be bred in other regions. Thus, the Estonian Red cattle breed expanded its area of distribution during the first half of the 20th century.

After the Second World War, the Estonian Red breed started to lose its superiority in distribution to the Estonian Black-and-White breed (Holstein) and after 1970, the ratio between the two breeds changed dramatically. The main reason for the change is that the Estonian Holstein breed is more productive as a dairy $\operatorname{cow}^{6}$ and that Estonian cattle breeding is predominantly dairy farming oriented. The analysis of the protocols of the Academy of Sciences from the Second World War on the development of agriculture in Estonia during the second half of 1940s shows that a significant amount of attention was paid to the breeding of pure-bred cattle, but no preference in breed was made. The protocols set forth that the main purpose of breeding was to increase the milk yield and the amount of fat in milk, to improve the meat output, and to breed the three most common cattle breeds in Estonia, including the native cattle. The regionalization of breeds was also mentioned as it was planned to breed Estonian Black-and-White cattle in the districts of industrial centres and holiday resorts and breed Estonian Red cattle in areas further from markets (Central and South-Estonia), where butter and cheese was produced. In more widespread areas, there existed a possibility to raise Estonian native cattle, which were ideal for producing milk with high fat content, in the form of micro-regions (Pung 1947). These protocols set a benchmark for the growth of Estonian Holstein cattle, as compared to Estonian Red cattle, simply because it was more productive as dairy cattle. Figure 2 shows that this growth was quite constant without major fluctuations. As of 2005, 70 percent of cattle in Estonia were of the Estonian Holstein breed.

6 E.g. in 2003, the average milk yield of the Estonian Holstein was 5,906 litres and of the Estonian Red 5,119 litres yearly (Pentjärv and Uba 2004). 


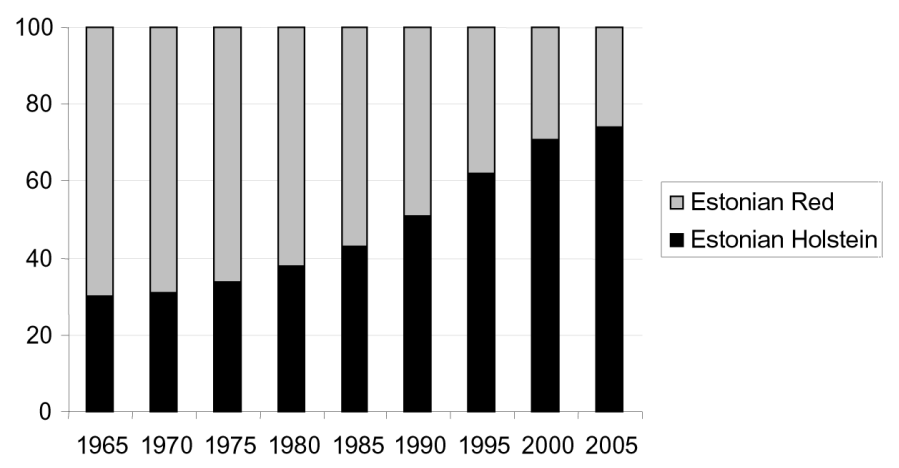

Figure 2. Ratio of the two most widespread cattle breeds from 1965 to 2005 (Pentjärv et al. 2005, ARIB 2005).

When analyzing the distribution of cattle breeds in greater detail, it can be noted that the historical-provincial distribution of cattle breeds between North and South-Estonia still exists today (see Figure 3). The only exception among the counties of the former territory of Livonia is that of Pärnu County, where Estonian

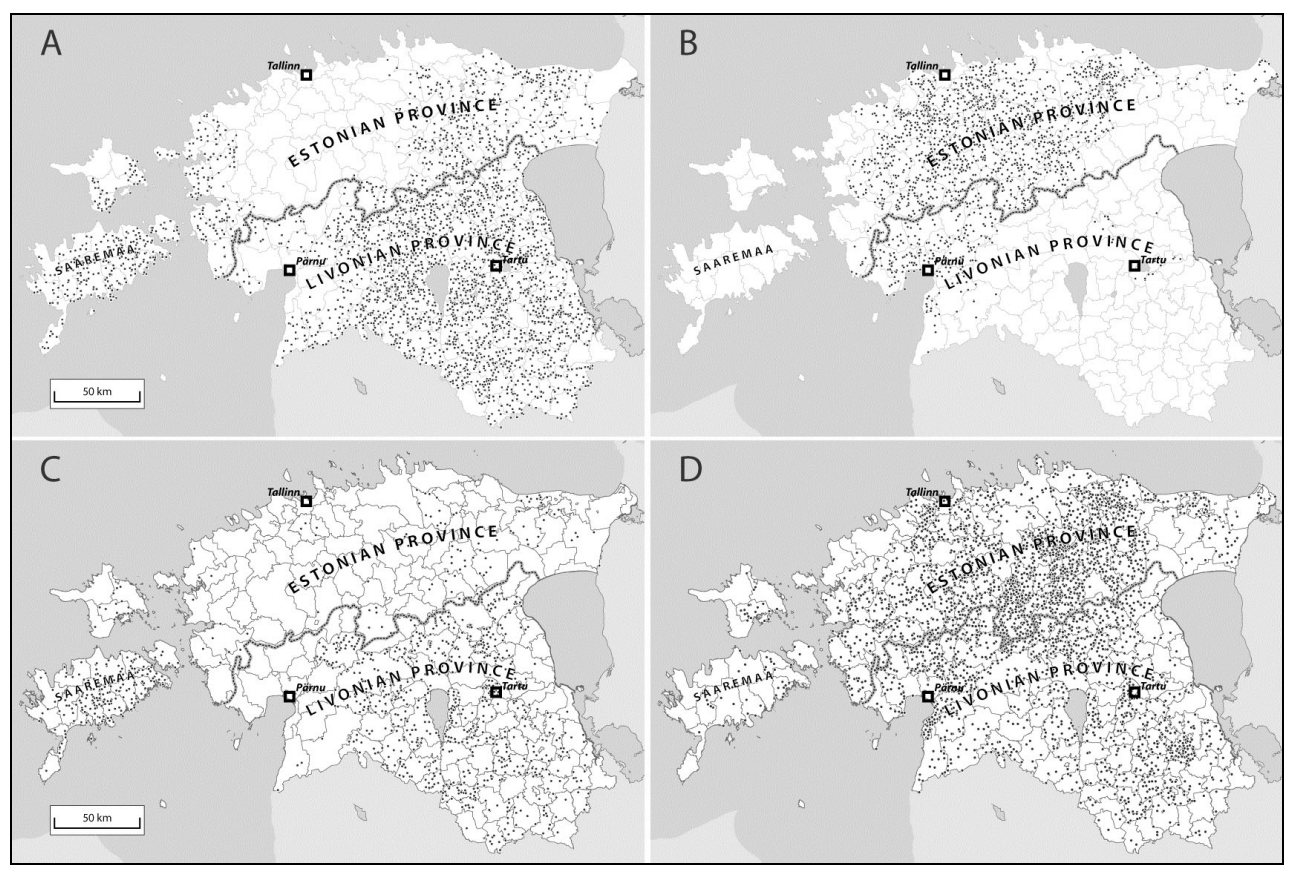

Figure 3. Distribution of Estonian cattle breeds in 1976 (A - Estonian Red; B - Estonian Holstein) and 2005 (C - Estonian Red; D - Estonian Holstein). Each dot signifies 100 cattle. The border between provinces represents the former administrative border which was the official division line until 1917. 
Holstein cattle were predominant until the end of the 20th century. In the other counties of South-Estonia, Red cattle were traditionally more common until the 1990s. There is no simple explanation for the popularity of the Estonian Holstein breed in Pärnu County. Even though its location and historical roots to Livonia make Pärnu County part of South-Estonia, its landscape, cultural, economic, and geographical characteristics, as well as dialect, are more similar to those of NorthEstonia. This might account for why the development patterns of cattle breeds in Pärnu County have been different from that of the rest of South-Estonia. Preference for the Estonian Holstein breed in Pärnu County may also be connected to historical persons involved with cattle breeding in the area. When the Livonian Dutch Friesian Cattle Breeders Association was established in 1901, Otto Hoffmann, the landholder of Sauga Manor (near Pärnu), was elected as the breeding inspector. Coincidentally, Hoffmann had worked for the Estonian Province Dutch Friesian Cattle Breeders Association; thus, the reason behind the popularity of the Black-and-White cattle in Pärnu County, over the Red cattle, could be attributed to the personal influence of Hoffmann. Upon the analysis of the data in the first Livonian Pedigree Book of the Dutch Friesian Cattle Breed, it stands out that this breed was represented in all the biggest manors of Pärnu County; in the manors of Taali, Sindi and Uulu (Stammbuch ... 1902). Lastly, at the beginning of the 20th century, focusing on one certain cattle breed might have been set as an example by the bigger and more progressive farms, like the Piistaoja farm of the Pool family in Tori parish (Pärnu County) where, again, Estonian Black-and-White were bred (Keevallik and Metsaalt 1981, Pool 1941). It is apparent that the favouring of the Estonian Holstein cattle breed in Pärnu County (especially in the areas surrounding the town of Pärnu) dates back to the very beginnings of cattle breeding there.

In North-Estonia, where mainly Estonian Holstein cattle are bred, the regions that differ from the norm are Ida-Viru County (eastern part of Estonian Province), Lääne County and the Island of Hiiumaa (western part of Estonian Province). While the popularity of the Estonian Red cattle breed in Lääne County and the Island of Hiiumaa can be explained by the compatibility of the cattle with the natural conditions there, their presence in Ida-Viru County remains unexplained.

Undoubtedly, the geographical distribution of cattle breeds in Estonia has been influenced by the so-called pedigree districts that were established in 1924 and divided the whole of Estonia into pedigree districts. Areas where several cattle breeds had been bred equally at the same time were named mixed districts. Prior to the establishment of these districts, farms that bred all three different steers could operate and receive state aid. Once districts were determined, farms were limited to only breeding specific breeds and exhibitions of young animals could be held only with approval of the district. If someone wanted to raise a different breed of cattle in a specific pedigree district, it had to be done at his own expense (Mägiste 1939). According to a map of pedigree districts in 1939, the distribution area of the Estonian Red cattle breed covered the counties of Valga, Võru, Tartu, Viljandi and Petseri and partially covered the counties of Pärnu, Järva and Viru; the core areas of the Estonian Black-and-White where Harju and Järva (Mägiste 1939). 
Estonia was also divided into breed regions during the Soviet period and these areas were decided by whether the area belonged to any industrial region or not. ${ }^{7}$ The districts of the Estonian Black-and-White cattle breed in Soviet times were the counties of Harju and Rapla. The counties of Paide, Pärnu and Rakvere were mixed districts and the rest of the counties were the districts of the Estonian Red cattle breed (Kutti et al. 1965). Estonian native cattle were not favoured during this period because its milk yield was insufficient and thus its number quickly decreased and it was usually replaced by the Estonian Red cattle breed that had managed to adjust to the natural conditions.

In general, the map of pedigree districts of 1939 agrees quite well with a map of pedigree districts of 1976. Thus, it can be concluded that preferring certain breeds in certain districts of Estonia remained almost unchanged for almost 40 years. Noticeable differences occurred only in Saaremaa and in West-Estonia. According to the map of pedigree districts of 1939, there were either only Estonian native cattle breed districts or mixed districts in West-Estonia. Nevertheless, by 1976, the Estonian Red cattle had gained a majority in West-Estonia and on the islands. Hence, it can be concluded that the Estonian Red cattle became dominant in West-Estonia and on the islands only after the Second World War.

After monitoring the changes in the geographical distribution of the cattle breeds over the last couple of decades (see Figures 3), it becomes evident that the Estonian Holstein cattle breed has expanded its 'area of influence' to a great extent. Saaremaa seems to be the only county where the Estonian Red cattle breed is still predominant. This can be explained by the conservative tendencies of the islanders; many elements of Estonian folk culture have been best preserved on the islands too (Viires 2004). The natural conditions of Saaremaa could also be considered an important factor for the Red cattle's presence. Due to its thin soil, the ground of Saaremaa is quite infertile and lacks suitable meadows and grasslands, which would require breeding a relatively small-sized and less nourishment demanding cattle there. Even though Estonian native cattle originally dominated the area of Saaremaa, the Estonian Red cattle had moved in and taken command by the end of the 1930s (Pung 1947). As demonstrated in the data from 1976, by that time, Saaremaa had clearly become an area full of Estonian Red cattle.

In the traditional Estonian Red cattle breeding counties of Southeast-Estonia, the Estonian Holstein cattle breed has taken over. This is most noticeable around the town of Põlva, where the biggest Holstein dairy cattle herds of South-Estonia are located (there are approximately 2,100 Holstein cattle in Põlva Agro LLC). From Table 2, it appears that from among the ten counties with the highest number of cattle, only the counties of Põltsamaa and Vändra have a noteworthy number of the Estonian Red cattle breed.

From the data of 2005, we can draw various conclusions from the sizes of cattle herds. While the average size of an Estonian Holstein cattle herd is 22, the

7 The majority of industrial regions were located in North Estonia. The main areas were in Tallinn and Ida-Viru County, where oil shale mines and electrical power generators were located. 
Table 2. 10 parishes in Estonia with the biggest amount of cattle in 2005 (ARIB 2005)

\begin{tabular}{l|c|c|c|c}
\hline \multicolumn{1}{c|}{ Parish } & $\begin{array}{c}\text { Estonian } \\
\text { Holstein }\end{array}$ & $\begin{array}{c}\text { Estonian } \\
\text { Red }\end{array}$ & $\begin{array}{c}\text { Estonian } \\
\text { Native }\end{array}$ & Amount \\
\hline Türi (Järva County) & 8,182 & 390 & 22 & 8,690 \\
Põltsamaa (Jõgeva County) & 4,489 & 1,267 & 3 & 5,779 \\
Väätsa (Järva County) & 5,530 & 64 & 0 & 5,601 \\
Kehtna (Rapla County) & 4,870 & 74 & 28 & 5,235 \\
Väike-Maarja (West-Viru County) & 4,493 & 501 & 2 & 5,096 \\
Märjamaa (Rapla County) & 3,841 & 41 & 107 & 4,615 \\
Vändra Pärnu County) & 2,149 & 2,154 & 99 & 4,492 \\
Põlva (Põlva County) & 3,723 & 501 & 3 & 4,308 \\
Vinni (West-Viru County) & 3,541 & 399 & 8 & 4,232 \\
Ambla (Järva County) & 4,074 & 55 & 0 & 4,134 \\
\hline
\end{tabular}

average number of an Estonian Red cattle herd is 11; half the size. Thus, it appears that Estonian Red cattle are bred in small-sized herds and farms. The size differences of cattle herds may be influenced by landscape conditions because the hilly landscapes of South-Estonia are usually more suitable for smaller herds, whereas the large plains of North-Estonia are more suitable for bigger herds. Most of the big herds in Estonia are of the Estonian Holstein breed ${ }^{8}$ and are located, as mentioned before, in North-Estonia. During the last decade, the breed diversity of cattle has increased greatly. Traditionally there have been three main cattle breeds in Estonia (Black-and-White, Red, and native cattle), but nowadays, there are altogether 15 different cattle breeds represented in Estonia (see Table 3). These new breeds are mainly beef cattle. The first Hereford beef cattle were imported in 1978 (Suurmaa and Toi 2004) and have become the most numerous among beef cattle breeds in Estonia. It is an interesting fact that in three parishes (Kõrgessaare, Noarootsi and Taheva), there were more Hereford beef cattle than traditional Estonian native cattle breeds in 2005.

According to the distribution map of Estonian folk culture, Estonia is culturally divided into North-Estonia, South-Estonia, and West-Estonia together with its islands (Viires 2004). The traditional distribution of cattle breeds re-emphasises this cultural-geographical division within the country. Besides differences of folk culture and cattle breeds, there are other historical differences, mainly in church history, within Estonia that also originate from administrative divisions (Schmidt 1991, Pae 2006). Additionally, resembling the old administrative border, an EastWest directional boundary of Silurian limestone and Devonian sandstone runs through Estonia (Mander and Palang 1994). Due to this geological border, traditional building materials of North-Estonia have always differed from those of South-Estonia. Likewise, regional dialects have separated North and SouthEstonia for centuries. As we can see, the current research on geographical distribu-

8 The biggest Holstein cattle herd in Estonia is located in Väätsa Parish in Järva County (Väätsa Agro LLC). The biggest Red cattle herd in Estonia is located in Vändra Parish (Vändra LLC). 
tion of Estonian cattle breeds is just one more indicator of the cultural-geographical differences of North and South-Estonia

Table 3. Cattle breeds in Estonia (ARIB 2005)

\begin{tabular}{l|r}
\hline \multicolumn{1}{c}{ Breed } & Number of cattle \\
\hline Estonian Holstein & 181,064 \\
Estonian Red & 62,248 \\
Hereford & 4,709 \\
Limousin & 4,224 \\
Aberdeen Angus & 4,215 \\
Estonian native & 1,754 \\
Charolais & 412 \\
Highland Cattle & 269 \\
Blonde d'Acquitaine & 210 \\
Piedmontese & 204 \\
Simmental & 129 \\
Belgian Blue & 122 \\
Jersey & 23 \\
Dexter & 8 \\
Schwyz & 2 \\
Total number of cattle & $\mathbf{2 5 9 , 5 9 3}$ \\
\hline
\end{tabular}

\section{Summary}

The following conclusions can be drawn from the current research on the geographical distribution of Estonian cattle breeds. As a result of the historical administrative division of Estonia between two provinces, the Estonian cattle breeds were geographically distributed into clearly defined districts until the 1900s. Systematic breeding work with cattle began in the second half of the 19th century and thus, responsibility for the coordination of cattle breeding was divided between provincial associations. Slight deviations from the provincially favoured cattle breeds occurred mainly in the counties of Ida-Viru and Pärnu. Besides the border between the two provinces determining the geographical distribution of cattle breeds, their distribution can be attached to regional political, cultural, natural, personal and economic conditions as well. The current research also discovered that the numerical distribution of cattle breeds has changed greatly during the last half of the 20th century. While the Estonian Red cattle breed was dominant in Estonia until 1900, the Estonian Holstein breed eventually took over and has gained a majority due to its ability to produce a higher milk yield than other breeds. ${ }^{9}$ The Estonian Red cattle's level of relative importance has fallen over time

9 The changeover of dominant cattle breed in Estonia has notably modified the overall imagery of cows. Thinking of a cow, first of all, brings to an Estonians' mind the black-and white cow of today instead of an image of the red cow that was so prevalent a couple of decades ago. The best illustrations of this today are the packages of milk products that frequently depict Holstein-type cows. 
and it now only constitutes approximately $1 / 4$ of the total cattle in Estonia. During the last 50 years, the number of Estonian native cattle, that has a low milk yield, has diminished to an extent where its survival has become questionable and it has been entered onto the endangered breeds list of FAO. Although cattle have been mainly used for dairy production, the number of beef cattle has increased in Estonia since its re-independence. As one can clearly see, the distribution, variety, and use of cattle breeds within Estonia has changed dramatically over the past several hundred years and these changes can be linked to the administrative borders that have existed throughout Estonia's history.

\section{Acknowledgments}

The writing of this paper was supported by the European Union through the European Regional Development Fund (CECT), the Estonian Ministry of Education and Research target funded research programme no SF0130033s07 'Landscape Practice and Heritage', no SF0180052s07 'Factors influencing spatial mobility of population and the impact on the regional development', and no SF0180049s09 'Landscape changes in Estonia related to global climate warming and human activity', and Estonian Science Foundation grant no. 6856 'Estonian National Landscape Imagery'.

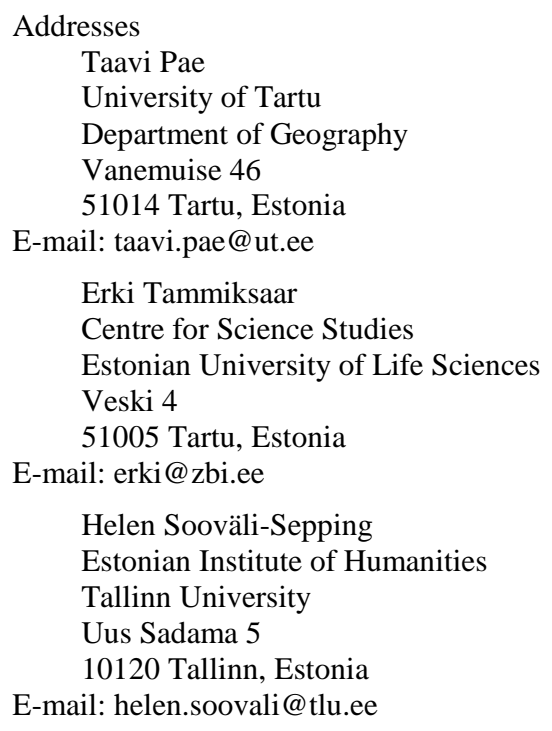

\section{References}

Baltische Wochenschrift (1863) Bd. 1, Nr. 1, 11.

Baltische Wochenschrift (1871) Bd. 9, Nr. 4-6, 68.

Baltische Wochenschrift (1879) Bd. 17, Nr. 5, 83-84.

Baltisches Stammbuch edlen Rindviehs 1885. 1886. Dorpat. 
Bodisco, E. M. von (1894) „Ergebnisse der Viehzuchtenquete des Estländischen Landwirthschaftlichen Vereins“. In Viehzuchtenquête des Estländischen Landwirthschaftlichen Vereins vom Jahre 1894, 31-43. E. M. von Bodisco, ed. Reval.

Bulitko, T.-T., E. Siiber and P. Padrik (2004) "Breeding of Estonian Holstein Cattle". In Animal Breeding in Estonia, 17-24. O. Saveli, ed. Tartu: Eesti Tõuloomakasvatuse Liit.

Eesti karjakontroll - aastaraamat XVII. 1938./39. kontrollaasta (1940) [Estonian cattle control - annual book XVII. 1938./39.] Tallinn.

Roos, J. ed. (1937-1940) Eesti rahvaleksikon. [Estonian popular lexicon.] Tartu: Noor-Eesti.

Frahm, K. (1982) Rinderrassen in den Ländern der Europäischen Gemeinschaft. Stuttgart: Enke.

Hupel, A. W. (1777) Topographische Nachrichten von Lief- und Ehstland. Bd 2. Riga: Johann Friedrich Hartknoch.

Idarand, H., ed. (1978) Veiste jõudluskontrolli tulemusi 1976. a. [Results of cattle recording in 1976.] Tallinn: Eesti Põllumajanduse Infokeskus.

Jaanhold, J. (1927) Loomakasvatus. Põllumajanduse peavalitsuse aastaraamat I, 1918-1926. [Livestock farming. Annual book of agricultural headquarters I.] Tallinn: Riigi trükikoda.

Kalamees, K. (2004) "Breeding of Estonian Native cows". In Animal Breeding in Estonia, 25-29. O. Saveli, ed. Tartu: Eesti Tõuloomakasvatuse Liit.

Kalamees, K. (2007) Eesti maakarja arengulugu: tõumonograafia. [Development story of Estonian native cow: breeding monograph.] Tartu: Halo Kirjastus.

Kant, E. (1935) Bevölkerung und Lebensraum Estlands: ein anthropoökologischer Beitrag zur Kunde Baltoskandias. Tartu: Akadeemiline Kooperatiiv.

Kantanen, J., Olsaker, I., Holm, L. E., Lien, S., Vilkki, J., Brusgaard, K., Eythorsdottir, E., Danell, B., and S. Adalsteinsson (2000) "Genetic diversity and population structure of 20 North European cattle breeds". Journal of Heredity 91, 7, 446-457.

Karelson, M. (1981) Lehekülgi Eesti põllumajanduse ja talurahva minevikust (kuni 1917. aastani). [Pages from the past of Estonian agriculture and peasentry (until 1917).] Tallinn: Valgus.

Keevallik, E. and M. Metsaalt (1981) "Vändra katsejaam meie põllunduskultuuri arendajana". [Vändra experimental station as cultivator of our agriculture.] In Pärnu linnas ja rajoonis, 8791. [In town and district Pärnu.] J. Eilart, ed. Tallinn: Eesti NSV Teaduste Akadeemia.

Keyserling, L. (1894) "Zur Geschichte der Viehzucht Estlands in den letzten 50 Jahren". In Viehzuchtenquête des Estländischen Landwirthschaftlichen Vereins vom Jahre 1894, 1-29. E. M. von Bodisco, ed. Reval.

Kivimäe, S. (1994) "Piimakasvatusele spetsialiseerumine Eestis". [Specializing in dairy cattle husbandry in Estonia.] Eesti Teaduste Akadeemia Toimetised, Humanitaar- ja Sotsiaalteadused [Proceedings of the Estonian Academy of Sciences. Journal of the Humanities and Social Sciences] 43, 2, 124-145.

Kukk, M. (2002) "Piimanduse areng Eestis kuni 1939. aastani". [Improvement of dairy farming in Estonia until 1939.] In Piimafoorum 2002, 37-40. [Milk forum 2002.] Tallinn.

Kutti, V., Pung, A. and L. Vaher (1965) Eesti mustakirju veisetõug. [Estonian Holstein breed.] Tallinn: Eesti Raamat.

Külvik, M., Sepp, K., Jagomägi, J. and Ü. Mander (2000) "Ecological networks in Estonia - from classical roots to current applications". In Multifunctional Landscapes. Vol. III: Continuity and change, 263-289. (Advances in Ecological Sciences, 16.) Wessex: WIT Press.

Lenstra J. A. (2006) "Marker-assisted conservation of European cattle breeds: an evaluation". Animal genetics 37, 5, 475-481.

Lepajõe, L. and Ü. Oll (1998) "Veisekasvatus". [Cattlebreeding.] In Teadus Eesti põllumajanduse arenguloos. I osa (kuni 1918. aastani), 69-72. (Akadeemilise Põllumajanduse Seltsi Toimetised, 5.) J. Kuum, ed. Tartu: Akadeemiline Põllumajanduse Selts.

Mander, Ü. and H. Palang (1994) "Changes of Landscape Structure in Estonia during the Soviet Period". GeoJournal 33, 1, 45-54.

Mägi, J. (1924) Angeli tõugu karja arendamise loost Eestis. [Improving Angler breed cattle in Estonia.] Reprint from Agronoomia. Tartu.

Mägiste, A., ed. (1939) Eesti punane tõukari 1919-1939. [Estonian red cattle herd 1919-1939.] Tartu: Eesti Punasekarja Tõuselts. 
Mölder, A. (1949) Eesti punane kari: tõumonograafia. [Estonian red cattle herd breeding monograph.] Tartu: Teaduslik Kirjandus.

Mölder, A. (1966) Eesti punase veisetõu aretus. [Selective improvement of breed of Estonian red cattle.] Tartu: Valgus.

Pae, T. (2006) Formation of cultural traits in Estonia resulting from historical administrative division. $\mathrm{PhD}$ thesis. Tartu: Tartu University Press.

Palmer, A. (2005) Northern Shores. A History of the Baltic Sea and its Peoples. London: John Murray.

Pung, A. (1985) 100 aastat veiste tõuraamatute pidamist Eestis. [100 years of herdbooks in Estonia.] Tallinn: Valgus.

Pentjärv, A. and M. Uba (2004) "95 years of animal recording". In Animal Breeding in Estonia, 14-16. O. Saveli, ed. Tartu.

Pentjärv, A., Kruus, M., and R. Tisler, eds (2005) Eesti Jõudluskontrolli Aastaraamat 2004. [The annual book of Estonian animal recording 2004.] Tartu: Elmatar.

Pistohlkors, G. von (2002) Deutsche Geschichte im Osten Europas: Baltische Länder. Berlin: Siedler Verlag.

Pool, T. (1941) Ergebnisse und Erfahrungen der Züchtungsarbeit des estnischen holländischfriesischen Rindes im Stammzuctbetrieb Piistaoja. Tartu.

PRIA (2005) Põllumajanduse Registrite ja Informatsiooni Ameti põllumajandusloomade register seisuga 2005 november. [Register of agricultral animals of the Department of Agricultural Register and Information as of November 2005.]

Pung, A. (1947) Tõuaretustöö aluseid Eesti NSV piimakarja taastamisel. [Basis of cattle improvement in recovering dairy cattle in ESSR.] Tartu: Teaduslik Kirjandus.

Põlluäär, T. (2004) "Breeding of Estonian Red Cattle". In Animal Breeding in Estonia, 22-24. O. Saveli, ed. Tartu: Eesti Tõuloomakasvatuse Liit.

Roosaare, J., Liiber, Ü., Aunap, R., Järvet, A., Pragi, U., and K. Tihemets (2000) Eesti geograafia [Elektrooniline teavik]. [Estonian geography.] Tallinn: Tiigrihüppe Sihtasutus.

Saveli, O (2006) "Tõuaretus". [Improvement of breed.] In Eesti põllumajandus XX sajandil, I osa, 268279. [Estonian agriculture in the 20th century, Part I.] A. Sirendi, ed. Tallinn: Põllumajandusministeerium.

Saveli, O (2007) "Tõuaretus". [Improvement of breed.] In Eesti põllumajandus XX sajandil, II osa, 534-539. [Estonian agriculture in the 20th century, Part II.] A. Sirendi, ed. Tallinn: Põllumajandusministeerium.

Schmidt, C (1991) "Über die Grenze zwischen Estland und Livland und ihre Bedeutung für die Agrarund Religionsgeschichte". Zeitschrift für Ostforschung 40, 500-521.

Stammbuch der Livländischen Holländer-Friesenviehzucht 1901 (1902) Jurjew.

Stegmann. P. (1924) "Geschichte der baltischen Rindviehzucht”. Landwirtschaftliche Jahrbücher 1923, $57,3,407-408$.

Sukhova, N. G. and E. Tammiksaar (2005) Aleksandr Fedorovich Middendorf, 1815-1894. Moskva: Nauka.

Suurmaa, A. and R. Toi (2004) "Estonian Beef Cattle Association and its History". In Animal Breeding in Estonia, 30-31. O. Saveli, ed. Tartu: Eesti Tõuloomakasvatuse Liit.

Tammiksaar, E. 2006. "Alexander Theodor von Middendorffi tegevus Liivimaa põllumajanduse edendajana ning tema seosed eesti rahvusliku liikumisega". [Activity of Alexander Theodor von Middendorff as promoter of Livonian agricultre and his connections with Estonian national movement.] In Vene aeg Eestis. Uurimusi 16. sajandi keskpaigast kuni 20. sajandi alguseni, 157-211. [Russian era in Estonia. Studies from mid-16th century to beginning of 20th century.] T. Tannberg, ed. Tartu: Eesti Ajalooarhiiv.

The chronicle of Henry of Livonia (1961) J. A. Brundage, transl. Madison: The University of Wisconsin Press.

The chronicle of Balthasar Russow (1988) J. C. Smith, transl. Madison: Baltic Studies Center.

Torok, I. 1995. "Cattle-breeding in Mezohegyes - the tradition obliges 1." Magyar Allatorvosok Lapja $50,9,525-527$.

"Verhandlungen der kais. Livl. Gemeinnützigen und Oeconom. Societät. Sitzung den 13. Januar 1864" (1864) Livländische Jahrbücher der Landwirtschaft 17 (1/2): 12.

Viires, A (2004) Old Estonian folk life. Tallinn: Ilo. 